A paper presented at a meeting of the Pittsburgh

Section of the American Institute of I lectrical

Engineers, Pittsburgh Pa., November 10, 1908.

Copyright 1908. By A.1.E.E.

(Subiect to final revision for the Transactions.)

\title{
ELECTRICITY IN MINES
}

BY GEO. R. WOOD

Before describing some typical coal-mining plants, with their especial features, the author will outline the ordinary mine development and some of the standard electrical mining equipment.

Assuming that the coal vein lies almost horizontally, with an average dip of, say, 1.5 to 4 or 5 per cent, the main headings or tunnels are driven to the raise where possible, so that grades will favor the loads. At intervals of about $1200 \mathrm{ft}$., crossheadings or flats are driven at right angles to the mains, and from these, parallel to the mains, are driven room-headings or entries, from 300 to $600 \mathrm{ft}$. apart. The rooms or chambers from which most of the coal is taken are turned from these entries, and are started in about the same width-10 ft.-as the entries. When in about $20 \mathrm{ft}$. they are widened out to full width-from 20 to $30 \mathrm{ft}$. These rooms are driven on about $40-\mathrm{ft}$. centers, leaving a pillar of coal between them from 10 to $20 \mathrm{ft}$. thick, to support the roof.

The thickness of coal in the Pittsburgh seam runs from 5 to $7 \mathrm{ft}$., in the Connellsville basin from 6 to $9 \mathrm{ft}$., and in central Pennsylvania from 3 to $5 \mathrm{ft}$. In a completely equipped electrical mine, the coal is undercut by electrical machines, hatuled from rooms to cross-headings by small gathering locomotives, and from cross-headings to main tunnels and thence to the tipple by larger locomotives. Electric pumps of various sizes handle the water; electric motors drive the fans which ventilate the mines; and car-hauls, crushers, elevators, and the like, where used, are also driven by motors.

Electrical mine locomotives and machines have been in use for 1095 
more than 20 years. Originally very crude and expensive to operate, they are now highly developed and satisfactory pieces of apparatus. Some of the first locomotives were made of streetcar trucks weighted down. Many were of the single-motor type, with connecting rods or with chain drive. The motors were not enclosed, and the trolley was of the pantagraph type. For a long time the equipment was inadequate, largely on account of the narrow gauge as compared with street-railway work, and also because each locomotive was proportioned for particular service, which afterwards increased as the haul was extended. The equipment was based on about 5.5 h.p. per ton, which will stand an intermittent service fairly well, but is not sufficient for long hauls or on heavy grades where sand is used.

Modern locomotives have usually two series motors, with a total capacity of about 10 h.p. per ton of locomotive weight. These motors are rated at 75 degrees cent. rise in $1 \mathrm{hr}$., or in some cases are rated for 40 - min. service. A rheostatic controller with grid resistance is used, and motors are operated in parallel on heavy pulls and in series for switching. The change is made by a four-point reversing cylinder. In a new controller for heavy work, each point on the controlling cylinder has a double-contact finger and a separate blow-out coil. Arc headlights are largely used.

In many mines it is desired to gather the wagons from rooms to cross-headings by motors. For this service small locomotives weighing from 4 to 6.5 tons are used, and since it is not desirable to have trolley wire in the rooms, these locomotives are provided with cable reels. These reels are arranged automatically to reel out cable when running into rooms, and reel it up again on coming out. The cable is hooked over the entry trolley and supplies current to the locomotives. The reel may be driven by a sprocket chain, through a friction clutch, from the axle of the locomotive or from the shaft of one motor. The reel may also be operated by a coiled spring, if the cable be not too long, or by a small series motor connected permanently in circuit. Where grades are very heavy against the load, a wirerope reel, with a small independent motor, is sometimes provided. In this case, the locomotive remains at the top of the grade, lowers the empty car by gravity and hauls up the loaded wagon by the wire rope.

Mainline four-wheel locomotives are not often made heavier 
than 14 tons, on account of the heavy rail required. When more power is needed, six-wheel, three-motor locomotives are used, of from 15 to 20 tons weight, or two four-wheel locomotives are coupled together with a single four-motor controller, and with the brake rigging operated from one lever. These tandem locomotives are sometimes so arranged as to be easily disconnected and worked separately when desired.

Electric coal-cutters were first of the "cutter-bar" type, in which the "bits" or small chisels were staggered around the surface of a horizontal cylinder, which was rotated and forced under the coal, making an undercut of a width and height equal to the length and diameter, respectively, of the cylinder cutter head. The next type was the chain-breast machine, which is very largely in use at present. This type comprises a stationary rectangular frame and a moveable frame, carrying the motor, gearing and cutter head, travelling within the stationary frame. The cutter head is the base of a long isosceles triangle, around which the chain is driven by a sprocket at the apex. This chain carries a number of cutters or bits, about one-third being uppers, one-third lowers, and one-third centers. The chain is fed forward into and under the coal by a rack-and-pinion feed, the cut being about 4 or 5 in. high and 44 in. wide. Both types of machines, after making a cut to the desired depth, are shifted side-ways; the operation is repeated until the face of the room is undercut completely across, after which the coal is blasted down.

A new type of machine is an electrically driven puncher. This puncher consists of a vertical motor with gearing, and a cylinder and two pistons, one of which is driven by the motor, the other carrying the cutting-tool or pick. The rear piston, driven by the motor, compresses air on its backward stroke, and the front piston, carrying the tool, is forced back by atmospheric pressure. At a certain point the rear piston passes a port which admits the compressed air between the two pistons. As the front piston is free to move, it is driven forward, causing the tool to strike the coal with great force. Should the pick not strike the coal, the blow is absorbed by an air cushion at the front of the cylinder. This machine is mounted on a pair of wheels, like the air puncher, and is operated in substantially the same way.

Another type of under-cutting machine is similar to the chainbreast machine, except that after making the first undercut, 
instead of withdrawing, moving sideways, and repeating the forward cut, this machine remains under the coal and is drawn sideways across the room, cutting as it goes. This type is especially adapted for cutting wide rooms or long faces, and is called a "long-wall" machine.

Machines have also been designed to cut and load the coal, without blasting. One of these is made up of two discs or cutting wheels about $4 \mathrm{ft}$. in diameter carrying bits in the periphery, mounted side by side and rotated in opposite directions. These are fed into the coal and undercut it, carrying the cuttings to the center, where a conveyor chain picks them up and feeds them back into a car. At the same time, two puncher machines, mounted above the wheels and one at each side, on swivels, are used to break down the coal as it is undercut, the cutter wheels throwing the coal to the center whence it is carried back by the conveyor. This machine as first designed is operated by compressed air.

Another machine has a double cutter head, like two standard chain machines, one above the other. The double head is swung in a vertical plane, describing an arc of about 180 degrees, like a steam shovel, except that the cutting is done on the downward stroke. This machine cuts the entire vein into fine slack, which is preferable for coking.

Electric mine pumping does not differ essentially from power pumping on the surface, except that the water is usually acid, and that grit and fine coal must often be handled. In the geared-type plunger pumps, the valve lift is increased to allow the passage of fine coal, etc., and the cylinders, plungers, valve seats and stuffing boxes are made of acid-resisting material. In some extreme cases cement-lined pumps with wooden plungers are used, or the entire pump is wood-lined. Where the water is not too strongly acid, and other conditions are favorable, turbine pumps are used, eliminating valves, packing, gears, etc. Rotary pumps of new design are also coming into use where the water does not contain much grit.

One of the first electrical mining plants in the.Pittsburg district was that at Grindstone, near Brownsville, $\mathrm{Pa}$. The generator was a bipolar machine of about $60 \mathrm{kw}$., driven by a Corliss engine through a countershaft. It is still in daily operation. Cutter-bar mining machines were operated.

The two largest plants at that period were those at Essen, near Carnegie, and Scott Haven, above McKeesport, both of 
which are now operated by the Pittsburgh Coal Company. The Essen plant supplied two mines, and consisted of three bipolar, 250-volt, 150-kw. generators, belt-driven. A number of mining locomotives were used, these having but one motor, carried lengthwise in the locomotive frame, with bevel gears at each end. On account of this positive connection to all driven wheels, and also on account of the steel-tired wheels, these locomotives had a very high draw-bar pull, but they were expensive to operate on account of the difficulty of holding the bevel gearing in line.

The Scott Haven plant, installed in 1895, supplied four mines, and consisted of four belted, 550-volt, 100-kw., fourpole generators. The switchboard was a skeleton oak frame, with round copper bus-bars, the switches being front-connected. On account of the high potential, a metallic circuit was provided for the mining machines as being safer for the men, but this circuit quickly became grounded in the mines. All the apparatus was later put on a grounded circuit with rail return.

The locomotives in the Scott Haven plant were of the twomotor type and mechanically of modern design. The motors were of about 23-h.p. rating on 10-ton locomotives. The armatures were cross-connected and were very difficult to rewind. These motors were replaced in 1898 by 35-h.p. motors for nar. row gauge use, originally designed, the author believes, for the Boston Elevated Railway. One of these locomotives has still in service the motor installed in 1898, the armature never having been taken out.

The installation at Scott Haven included some of the earliest motor-driven fans and pumps. Practically all of these are still in use.

One of the first direct-connected plants was installed in 1897 at Moon Run, about 5 miles West of McKees Rocks. This plant was first used for haulage alone, and included one $165-\mathrm{kw}$., 250 -volt generator, driven at $240 \mathrm{rev}$. per min. by a center-crank engine. Another unit was installed later with a side-crank engine, but before this was in place the center-crank engine shaft broke in the disc. It was operated for several weeks after breaking in two, until the other unit could be started.

One of the first alternating-current central plants for coalmining purposes was installed in 1902 at Gary, W. Va. This plant first contained two 400-kw., 6600-volt, 25-cycle generators, driven by twin simple engines with independent governors. 
The exciting equipment consisted of one $25-\mathrm{kw}$. vertical enginedriven unit and one $25-\mathrm{kw}$. generator direct-driven by a $40-\mathrm{h}$.p. induction motor at $720 \mathrm{rev}$. per min. All oil switches were in brick cells back of the switchboard, with remote manual control, the feeder switches being of the automatic overload release type with time limit relay. The generator switches were non-automatic.

The longest transmission was originally 3 miles. Three substations were built, each containing one 150-kw., 275-volt converter with step-down transformers and the usual switchboard equipment. Each sub-station also contained step-down transformers for induction motors at tipples, etc. Direct current from the converters was used for haulage only, supplying mainline and gathering locomotives of the cable-reel type, and the larry equipments for the coke ovens. These larry equipments included one motor with a reversing controller, resistance and trolley, and the motors were duplicates of those on the smaller locomotives. Each larry could haul one trailer.

Induction motors are used on single-stage, two-stage, four stage and five-stage turbine pumps, for coke oven supply; on crushers in sizes of $75,200,300$ and 400 h.p. at the tipples; on mine fans, for which purpose two-speed, changeable-pole, 100-h.p. and 150-h.p. motors are used; for driving deep-well pumps and small compressors for air lift, with silent-chain drive; and for driving picking tables, car hauls, conveyers, etc. at tipples.

This plant was later increased by adding two $750-\mathrm{kw}$., 6600 volt generators, driven by cross-compound Corliss engines at $125 \mathrm{rev}$. per min. At the same time the original twin simple engines on the smaller units were changed to cross-compound, giving better regulation and economy. Within the past year one $1000-\mathrm{kw}$. steam turbine on $140 \mathrm{lb}$. pressure has been added, also one $1000-\mathrm{kw}$. low-pressure turbine, using exhaust steam from the engines. Condenser equipment, including three large cooling towers, has been provided for the turbines.

Nine sub-stations are now in operation, and three $500-\mathrm{kw}$. step-up transformers, 6600 to 22,000 volts, have been installed for supplying mines to be opened about 12 or 15 miles distant.

A very economical plant has been installed near Fairchance, $\mathrm{Pa}$., utilizing in the boilers the waste heat from the coke ovens. A large flue is built back of 100 bank ovens, with smaller flues connecting each oven, and a boiler plant is located at the center 
of each section of 50 ovens. Thus each boiler plant draws from 25 ovens each way, making a travel of about $350 \mathrm{ft}$. for the hot gases. The engine room is half way between the boiler plants, and contains four 400-kw., 2300-volt, 25-cycles, three-phase generators, driven by cross-compound engines. By means of five sub-stations this plant now supplies seven works, operating locomotives, larry equipments, car hauls, conveyers, fans, pumps and coke-drawing machines. Up to the present time it has been found necessary to operate but one boiler plant, but cxtensions are under way which will absorb the entire capacity of the plant, one of the additions being a 1000-cu. ft., 1000-1b. motor-driven compressor for supplying air locomotives in a gaseous mine. When the demand for power increases, it is expected to install a low-pressure turbine with condensers, which would give about $1000-\mathrm{kw}$. additional when operating three engine units.

At Ellsworth, $\mathrm{Pa}$. it was expected ultimately to install an alternating-current central station, and belt-driven synchronous converters were installed for temporary use as three-wire direct-current generators. A neutral was obtained from the collector rings through the secondaries of small 200-volt transformers, and this neutral was permanently grounded to the mine tracks. Locomotives, machines, and pumps were operated at 275 volts between either main lead and the track, the load being balanced as nearly as possible, while outside motors, on fans, etc. are connected across 550 volts. It was found th at straight star connections to the neutral from the collector ring through transformers would not work, as the converters bucked badly until interconnections were made to neutralize the flux in the transformers due to unbalanced direct current. It was also clearly demonstrated that the old style converters are much better adapted for use as direct-current generators than the modern design. The first ones installed were built 7 or 8 years ago and operated well with proper attention. One or two new ones could not be operated successfully at more than onehalf rated capacity.

Three-wire, direct-current plants are also in operation in West Virginia, using railway type generators, with derived neutral through balancing transformers. One of these plants, at Minden, W. Va., operates three 300-kw., 600-300-volt generators, driven by cross-compound engines, and supplies four mines. The apparatus in use includes 20 locomotives, 16 machines, 21 pumps and 14 fan, car-haul, and miscellaneous motors. 
The three-wire system has the advantage of being less dangerous than that using 550 volts pressure; the return or bonding need not be so good, and motors, etc. stand up better. The two voltages are also useful for variable-speed requirements. It is objected to on account of the care required in balancing the circuits. As a transmission problem, it is, with perfect balance, a 600-volt metallic circuit, and therefore requires just twice the copper-neglecting the difference in bonding-as a 600volt, grounded-return system, or half the copper as compared with a two-wire, 300-volt grounded system. The balancing is most effective when a large number of small units are operated. The unbalanced current at Minden rarely exceeds 15 per cent.

In Woodward, Alabama, a plant has been installed at the furnaces of the Woodward Iron Company, taking steam from the furnace boiler plant, normally fired by blast-furnace gas.. The plant includes three 400-kw., 3500-volt, 25-cycle, three-phase generators, with cross-compound engines. At or near the furnaces two two-stage turbine pumps, delivering 3000 gal. per minute each against a 135 -ft. head, are operated for furnace use, while two 100-kw. motor-generator sets supply 250-volt direct current to shop motors, small locomotives handling ore wagons, and a travelling crane handling hot iron on the casting floor.

At No. 1 coal mine, about 2.5 miles away, the current is taken underground in a three-conductor, varnished-cloth insulated, steel-armored cable. Four thousand feet inside are two 700gal. triplex pumps chain-driven by two 150-h.p., 3300-volt, induction motors and working against a 550-ft head. A few thousand feet farther in is an endless rope haulage, chain-driven by a variable-speed, 3300-volt motor, running at 200-480 rev. per min., with a controller and secondary resistance. About two miles from the pit mouth is an underground sub-station, containing one $200-\mathrm{kw}$. converter with step-down transformers, etc., supplying 275-volt current to mine locomotives. A number of small triplex pumps, operated by 440 -volt induction motors, are also in use.

At No. 2 coal mine, about two-thirds of a mile farther from the power plant, current is taken underground approximately two miles to a duplicate sub-station, also supplying locomotives, and up an air shaft to a 50-h.p., 3300-volt motor driving a mine fan. On account of the frequent labor troubles in that district, it was not advisable to take any power overhead, except along the railroad to the coal mines, where the line could be patrolled. 
The plant is now being enlarged to provide power to the ore mines, three miles from the plant in another direction, to operate hoists, crushers, pumps, and air compressors for rock drills.

The six 150-h.p., 3300-volt motors on turbine pumps, triplex pumps, and motor-generator sets are duplicates. The underground cable is suspended from a messenger wire, with frequent loops for expansion and repair. There have been several rockfalls on the cable, most of which have caused short-circuits, but repairs are easily made. The armor is protected against corrosion by a layer of jute and asphalt, but the miners have cut a good deal of this off for kindling to start fires. They also stole about 40 gallons of oil out of the substation transformers one night, for use in their lamps.

These mines go in on a slope of about 20 per cent for the first mile, after which the vein flattens out. There is only. about 4 $\mathrm{ft}$. of headroom. A good deal of the underground apparatus was skidded down on the track rails.

At Ehrenfeld, near Johnstown, is a plant in which belt-driven converters were first used for generators, supplying an underground substation through step-up transformers from 165 to 5600 volts. This substation contained, besides the necessary step-down transformers, one 250-kw., 275-volt converter, operating on the trolley in parallel with the direct-current side of the double-current generators. This was the first alternatingcurrent plant operating underground substations. Larger direct-connected generators have since been installed. It was the intention to use the original generators as converters later.

At Yatesboro, Pa., there is a successful installation, operating a number of motor-driven compressors, fans and sub-stations. The station equipment includes two $1500-\mathrm{kw}$., 60-cycle turbine units, generating three-phase current at 6600 volts. In two substations are installed 300-kw., 550-volt converters running at $900 \mathrm{rev}$. per min. and in a third a motor-generator set, with an induction motor driving a 300-kw., 550-volt generator. Three motor-driven fans are in use at different mines, one with a 250-h.p. motor, belt-driven, one with a 250-h.p. motor and silent-chain drive, and a third with a 400-h.p. motor direct-connected through a flexible coupling. There are also, at the various mines, eleven 1400-cu. ft. duplex compressors, belt-driven by 250-h.p., 6600-volt induction motors. One interesting feature of this plant is that these high-tension induction motors are all started by throwing directly on the line. 
At Windber, Pa., there have been operating, until this year, eight direct-current power plants supplying 12 mines. Two of these plants, those at No. 36 and No. 40 mines, are efficient installations with cross-compound condensing Corliss units. water-tube boilers, etc., but the range of distribution was such that the loss in transmission overcame the efficiency in the plants.

In most of the mines locomotives only were operated, at 550 volts, and the transmission was from 1.5 to 2.5 miles. Compressed-air " puncher-type" mining machines and compressedair pumps were used, with steam engine-driven fans. It was decided to centralize the power, to do away with all the directcurrent power plants, except No. 36 and No. 40, and to limit their field to a radius not exceeding 1.5 miles. The boilers from some of the dismantled steam plants have been assembled and a plant installed at No. 35 mine, in nearly the center of the field. The equipment includes one 400-kw., 6600-volt, three-phase, 25-cycle generator, driven by a cross-compound engine, and two $1000-\mathrm{kw}$. steam-turbine units to operate at $140 \mathrm{lb}$. pressure and $1500 \mathrm{rev}$. per min. One additional turbine unit, probably of $3000-\mathrm{kw}$. capacity, will be installed early next year.

The 400-kw. engine-driven unit, with two 200-kw. converters, was purchased some years ago. These converters with one additional, will be installed at No. 38 mine and also supply No. 39. At No. 33 mine and also to supply the front end of No. 34 , will be located two 150 -kw., belted-type, 550-volt generators. formerly used at No. 30, now to be direct driven by 225-h.p., 6,600 -volt synchronous motors at $j(0)$ rev. per min. In this substation will also be installed one $180(0$-cu. ft., 2-stage air compressor, direct-driven by one 300 -h.p., 6600-volt, synchronous motor at $187 \mathrm{rev}$. per min. In a substation at the back end of No. 34 mine, also supplying No. 31 mine, will be located one 300-kw. converter and two direct-driven $1800 \mathrm{cu}$. ft., 2-stage compressors.

At No. 41 mine electric puncher machines are supplied with 250-volt current from a $100-\mathrm{kw}$. generator driven by a $150-\mathrm{h} . \mathrm{p}$. 440 -volt induction motor at $750 \mathrm{rev}$. per min.

At No. 42 mine two $300-\mathrm{kw}$, 550-volt converters are installed, to operate locomotives in two drifts, one in each vein of coal, and also to feed into the back end of No. 36 .

At No. 35 shaft, two miles back from the pit mouth is located a large fan to ventilate No. 35 and parts of No. 36 and No. 40. This fan will be driven by a 400-h.p., variable-speed, 6600-volt 
motor, direct-connected through flexible coupling, to operate at 200 to 285 rev. per min. A substation here contains two $300-\mathrm{kw}$. converters, with space reserved for one more, also six $150-\mathrm{kw}$. transformers, with a 6600-440-volt ratio supplying two large pumps at the shaft bottom. A drainage level was located across mines Nos. 37, 40, 35, 36 and 42, all the water above which will flow by gravity to this shaft. Here will be placed two two-stage turbine pumps, each of 4000)-gal. capacity per minute against a 3:30-ft head, and each will be driven by a 500-h.p., 440-volt induction motor at 730 rev. per min. These pumps will replace over 70 compressed-air and steam pumps.

A sub-station will be located at the rear end of No. 37 mine, and contain one $300-\mathrm{kw}$. converter, and later one motor-driven compressor. This converter will work in parallel with No. 40 direct-current plant, supplying the outside haulage, etc.

$A \mathrm{n}$ induction motor has been designed for the electric coal puncher, or "pneumelectric" machine, and it is expected, if this proves a success, to replace the compressed-air punchers wherever found practicable. On account of the large investment in machines, pipe, etc. some mines will still be operated by air, as No. 33, 34, 31, 37 and 40 , and wherever necessary for best economy motor-driven compressors will be located near the work, displacing steam-driven machines.

The output of these mines is normally about 18,000 tons per day. The cost per ton has been slowly but steadily increasing from year to year, as the mines advanced, and transmission lines and water lines lengthened. It is expected to increase this output as desired to over 20,000 tons per day, and to reduce the cost at least 6 cents per ton. This cost should then increase but very slightly for probably the next 5 or 10 years.

The cost of the electrical equipment, including foundations, buildings and installation, will approximate $\$ 250,000$, and the total cost of improvements; such as shafts, drainage tunnels, etc., will amount to about $\$ 600,000$. 